\title{
The Binary Logistic Regression In Modeling The Factors Of E-Banking Using For Students
}

\author{
Garindra Widhiatma Suganda ${ }^{I^{*}}$, Rendra Erdkhadifa $^{I}$ \\ ${ }^{1}$ Islamic Banking Department, Faculty of Economic and Islamic Business, UIN Sayyid Ali \\ Rahmatullah, Indonesia
}

\begin{abstract}
This research is motivated by one of the technology-based banking services, namely electronic banking. In the industrial revolution 4.0, e-banking is currently a major concern and as a bank's operational strategy for a competitive tool in marketing in the world of financial services. In winning this competition, banks need a strategy to be able to attract customers to use e-banking services in order to retain customers and increase banking profitability. This study aims to examine and analyze the effect of convenience, benefits, security, convenience and knowledge on interest in using e-banking. The research method used in this study is quantitative, using a technique purposive sampling method. The sample in this study were students of the Islamic Banking Department IAIN Tulungagung and obtained as many as 268 respondents as the research sample. The data analysis technique used binary logistic regression analysis using the SPSS 21.0 program. The results of data analysis in this study indicate that the variables of convenience, benefit, security, comfort and knowledge have a positive and significant effect on interest in using e-banking. The implication of this research is that convenience, benefit, security, convenience and knowledge have an equally important role in increasing interest in using ebanking.
\end{abstract}

\section{Introduction}

The development of technology at this time is increasing. The impact of technological developments is not only felt by some people, but almost all levels of society. Technology is now present in almost every human activity, in addition to helping work become more practical, technology is also able to provide all kinds of information needed by humans. Information technology is not only used to find information, but is also used to conduct economic transactions (Sumarwan, 2011).

Utilization of information and communication technology as a means of conducting economic transactions can have an influence on almost all industrial sectors of the world's economy. One sector that is also affected by the development of information and communication technology is the banking industry. The role of information technology in the banking world, especially in Indonesia, is very difficult to separate. Information

\footnotetext{
* Corresponding author: rendra.erdkhadifa@gmail.com
} 


\section{$A I \bar{C} \quad$ Annual International Conference \\ on Islamic Economics and Business, 2021}

technology is the main supporter in the banking system, because the progress of a banking system is supported by the role of information technology (Pratama et al, 2019).

The use of information technology in the banking industry focuses more on service systems. This is because the bank is one of the companies engaged in services, where customer satisfaction is determined by the quality of service. In addition to good service, supporting facilities that can facilitate transactions also affect customer ratings of a banking product. Banks generally use information technology as a tool to meet the needs of interaction between banks and customers, where customers can obtain information and conduct banking transactions. One of the services provided by banks to meet these needs is Electronic banking.

In the e-banking wise book published by OJK (Financial Services Authority), Electronic banking or e-banking is a service that allows bank customers to obtain information, communicate and conduct banking transactions through electronic media. The service ebanking is currently owned by almost all banks in Indonesia, such as Automatic Teller Machine (ATM), Electronic Data Capture (EDC) / Point Of Sales (POS), internet banking, SMS banking, mobile banking, e-commerce, phone banking , and video banking. This is in line with the trend of the development of existing information technology to realize transactions not always with cash, so that many economic actors or the public take advantage of modern banking services that are more efficient and effective through e-banking (Marsudi \& Widjaja, 2019).

The rapid development of e-banking is because the banking world has entered the era of the industrial revolution 4.0, which is marked by the full use of information and digital technology. In industry 4.0 there are 5 things that mark, namely Artificial Intelligence (AI), Internet of Things (IOT), human-machine interfaces, robotic and sensor technology and three-dimensional printing technology. These five technologies are a sign that in this era, the industry will enter the virtual world and the use of automation machines.

In the industrial era 4.0, it is an opportunity for banks to be more innovative in providing services to customers through e-banking. These innovations are needed to respond to competition in the financial services industry and to respond to the lifestyle of people who are more interested in fast, easy and efficient services. In addition, technology-based banking services present a number of challenges such as protecting customer data security, anticipating system errors and user risks related to cybercrime (Nelson, 2015). This requires banks to adapt more quickly to maintain customer interest in using e-banking services because otherwise the banking system will be abandoned by its customers.

The service e-banking can be a solution for customers amid the industrial revolution 4.0 so that it can be used in conjunction with digital technology and machine automation. The use of e-banking for customers is to provide ease of transaction in terms of time, place, and cost. Customers do not need to visit the bank office to obtain information or perform banking transactions, because this can be done through digital banking services or ATM machines

The benefits that can be obtained from the use of e-banking services are quite a lot, it is expected to be able to attract various groups of customers, one of which is students and especially Islamic banking majors. Students majoring in Islamic banking should have awareness in the application of the use of e-banking. Accountability for the knowledge that has been obtained and practicing all the theories learned is one of them by using e-banking service facilities. The importance of e-banking services for students is that students can use this service quickly and efficiently in the midst of busy lecture activities. In addition, the use of e-banking can provide benefits and make it easier for students to carry out economic activities such as financial transactions.

Interest in using e-banking in this study is defined as the tendency of individuals to act before the decision to use e-banking is actually implemented. Individual interest arises because there is an interest in a particular thing. The more individuals are attracted to the 


\section{$A \mathrm{IC} \quad$ Annual International Conference \\ on Islamic Economics and Business, 2021}

relationship, the greater the individual's interest. The emergence of interest will encourage a person to gain understanding and skills to achieve desires (Rahmat, 2018). Determination of interest in the use of e-banking is influenced by several determining factors in making decisions.

A person's acceptance of information technology is influenced by two main variables, namely convenience and benefits. The increase in instrumental convenience affects the increase in benefits because an easy-to-use system does not take long to learn so that individuals have the opportunity to do something else that is related to performance effectiveness. Based on the description above, the authors will analyze the factors that are thought to influence student interest in using e-banking using a binary logistic regression approach. Therefore, the authors are interested in conducting research with the title "The Binary Logistic Regression In Modeling The Factors Of E-Banking Using For Students"

\section{Theories}

\subsection{Interest}

Interest is an attitude that takes place continuously within a certain period of time, thus making an individual more selective towards the object of interest, feelings, work, activity, the most valuable object or making the individual more motivated, which leads the individual to a certain direction (Chaplin, 2008). Interest is defined as the desire from within a person to do something without anyone asking. Interest arises because there is an interest in a particular thing. The more someone is interested in the relationship, the greater the person's interest (Slamet, 2010). The emergence of interest will encourage a person to gain understanding and skills to achieve desires. Interest is someone's motivation that can encourage someone to do what they want, then if they can freely choose and see the benefits according to what they want, then interest will arise in them (Yahya \& Putri, 2016). Interest is the tendency to be interested in something relatively fixed to pay more attention and remember continuously which is followed by a sense of pleasure to obtain satisfaction in achieving technology user satisfaction.

\subsection{E-Banking}

E-banking is a banking transaction that uses the internet network with a banking website to make payments, telephone bills, and others. In the wise book of e-banking, e-banking is a service that allows bank customers to obtain information, communicate, and conduct banking transactions through electronic media such as Automatic Teller Machine (ATM), Electronic Data Capture (EDC) / Point Of Sales (POS), internet banking, SMS banking, mobile banking , e-commerce, phone banking, and video banking (Nelson, 2015).

\subsection{Convenience}

Ease of use is defined as the extent to which a person believes that using a technology will be effort-free. Ease of use as a person's level of confidence that using a particular system does not require a lot of effort. Although the effort according to each person is different but in general to avoid rejection from system users on the developed system, the system must be easy to apply by users without expending burdensome effort, the intensity of use and interaction between users and the system can also show ease of use. Ease of use of a technology is defined as a measure by which a person believes that the technology can be easily understood and used (Popi, 2010). 


\section{$A I \overline{C E B} \quad$ Annual International Conference \\ on Islamic Economics and Business, 2021}

\subsection{Benefit}

Benefit of use is an individual's belief in the use of a technology and assumes that technology can improve its performance to be more effective (Jogiyanto, 2008). An individual can benefit from technology services if they understand and know how to apply these services properly. Adamson and Shine define benefit as a form of individual trust in the use of a particular technology and is believed to be able to improve the individual's performance. From the explanation above, it can be concluded that the perception of benefits arises as an assumption that is believed by an individual towards the use of technology and is felt to be able to increase effectiveness in work.

\subsection{Security}

Security according to Potter and Perry is a condition in which a person is free from physical and psychological injury and is in a safe and secure condition. Safety is a second level need after basic needs. This is a need for protection for the human body. Physical security will lead to a sense of psychological security, because consumers do not feel anxious and worried and their lives are threatened wherever they are (Sumarwan, 2003). Security is the ability to protect consumer information or data from fraud and theft in the online banking business (Zahid et al, 2010). Information security is how we can prevent fraud ( cheating ) or at the very least, detect fraud in an information-based system, where the information itself has no physical meaning. Security threats are misuse of both network transactions and transmission of data through unauthorized access to accounts by means of fake authentication. It can be concluded that the security in using e-banking is the guarantee of funds and customer data from the risk of loss or theft when conducting transactions.

\subsection{Comfortable}

Comfort is a condition of feeling someone who feels comfortable based on the perception of each individual. Feeling comfortable is a condition where the basic needs of individual human beings have been fulfilled due to several factors of environmental conditions. Convenience is a state where the individual believes that the activities of using the system are considered enjoyable for him and using a system including the performance consequences caused by using the system. If using the system is felt to be fun, then the users will be motivated to use it so that the assumption that the perception of comfort will have a positive effect on the use of the system. A customer uses a system if he feels comfortable with the system (Widianingsih et al, 2017). Creating a convenience for consumers there is also a dimension of decision convenience, namely consumer perceptions of time, cost, and effort to make purchasing decisions or use services (Tjiptono, 2004).

\subsection{Knowledge}

Knowledge is a change in the behavior of an individual derived from experience (Rizky et all, 2018). According to Mowen, consumer knowledge is defined as a number of experiences with information about certain products and services that a person has. A consumer has different levels of knowledge, which can be used to interpret information and make decisions. An increase in consumer knowledge can make it possible for consumers to be able to make a difference between various other brands. Consumer knowledge is defined as the subset of the total information relevant to the consumer's function in the market. 


\section{Research Method}

\subsection{Research Type and Approach}

In this study the author uses a quantitative approach. Quantitative approach is a research method used to examine certain populations or samples, collect data using research instruments, analyze quantitative or statistical data with the aim of testing predetermined hypotheses (Sugiyono, 2004). The type of research used in this study is associative research. Associative research aims to determine the relationship between two or more variables (Sugiyono, 2018).

\subsection{Population, Sampling, and Sample}

The population to be studied in this study is all students of the Islamic Banking Department, Faculty of Islamic Economics and Business, IAIN Tulungagung class of 2017 and 2018. The sampling method in this study is purposive sampling. The technique for determining the number of samples with an error rate of $5 \%$ is by using the Slovin formula, as follows:

$$
n=\frac{N}{1+N e^{2}}=\frac{811}{1+811(0.05)^{2}}=268
$$

The sample used in this study was 268 respondents from the Islamic Banking Department, Faculty of Islamic Economics and Business IAIN Tulungagung/

\subsection{Data Sources, Variables, and Measurement Scales}

The independent variables in this study include convenience (X1), benefits (X2), security (X3), convenience (X4) and knowledge (X5), and the dependent variable in the study includes student interest in using e-banking (Y). The measurement scale used in this study is a nominal scale.

\subsection{Data Analysis Method}

Binary logistic regression is a method of regression analysis that describes the relationship between the response variable (dependent) and one or more predictor variables (independent). In binary logistic regression, the given model with p predictor variables is as follows:

$$
\pi(x)=\frac{\exp \left(\beta_{0}+\beta_{1} X_{1}+\beta_{2} X_{2}+\ldots+\beta_{p} X_{p}\right)}{1+\exp \left(\beta_{0}+\beta_{1} X_{1}+\beta_{2} X_{2}+\ldots+\beta_{p} X_{p}\right)}
$$

\subsubsection{Simultaneous Test}

This test was conducted to determine the effect of predictor variables on response variables simultaneously (together). The hypotheses used in this test are:

$\mathrm{H}_{0}: \beta 1=\beta 2=\ldots .=\beta \mathrm{p}=0$

$\mathrm{H}_{1}:$ at leats one $\beta \mathrm{i} \neq 0$

$\mathrm{i}=1,2, \ldots, \mathrm{p}$

$\mathrm{p}=$ number of predictor variables

Test Statistic: G test statistic or Likelihood Ratio Test, namely 


\section{$A \overline{C F B}$ Annual International Conference \\ on Islamic Economics and Business, 2021}

$\mathrm{G}=-2 \ln \left[\frac{\left(\frac{\mathrm{n}_{1}}{\mathrm{n}}\right)^{\mathrm{n}_{1}}\left(\frac{\mathrm{n}_{0}}{\mathrm{n}}\right)^{\mathrm{n}_{0}}}{\prod_{\mathrm{i}=1}^{\mathrm{n}} \pi_{\mathrm{i}}^{\mathrm{y}_{\mathrm{i}}}\left(1-\pi_{\mathrm{i}}\right)^{1-y_{\mathrm{i}}}}\right]$ (3)

$\mathrm{n}_{0}$ : the number of observations for $\mathrm{y}=0$

$\mathrm{n}_{1}$ : the number of observations for $\mathrm{y}=1$

Critical Area : $\mathrm{G}>\mathrm{X}_{(\mathrm{db}, \alpha)}^{2}$

\subsubsection{Individual Test}

Affiliations of authors should be typed in 9-point Times. They should be preceded by a numerical superscript corresponding to the same superscript after the name of the author concerned. Please ensure that affiliations are as full and complete as possible and include the country. This test was conducted to determine the effect of predictor variables on individual response variables. The hypotheses used in this test are::

$\mathrm{H}_{0}: \beta \mathrm{i}=0, \mathrm{i}=1,2, \ldots \mathrm{p}$

$\mathrm{H}_{1}: \beta \mathrm{i} \neq 0$

Test Statistics : Wald Test Statistics

$\mathrm{W}_{\mathrm{i}}=\left(\frac{\beta_{\mathrm{i}}}{\operatorname{SE} \beta_{\mathrm{i}}}\right)^{2}$

Critical Area: $\mathrm{W}_{\mathrm{i}}>\mathrm{X}^{2}(\mathrm{db}, \alpha)$

\subsubsection{Goodness Of Fit Test}

After the estimation of the logistic regression model is obtained, the next step is to test the suitability of the prediction results of the model in explaining the response variables with the results of observations. According to Hosmer and Lemeshow, this is called goodness-offit (model fit). The hypotheses used are:

$\mathrm{HO}$ : the model fits (there is no significant difference between the observed results and the possible predictions of the model).

H1 : the model does not fit (there is a significant difference between the observed results and the possible predictions of the model)

\section{Result and Discussion}

In the multivariate binary logistic regression analysis section, it is used to find out what variables are appropriate in measuring the response variable and the suitability of the model formed with a significance level of $5 \%$

\subsection{Model Significance Test}

Model significance test analysis was used to determine the most significant model in describing the predictor variables to the response variables. This needs to be done, because in the multivariate binary logistic regression analysis, backward elimination is carried out to get the right model. The following are the results of the analysis of the significance of the model as shown in Table 1.

Table 1. Model Significance Test

\begin{tabular}{|c|c|c|}
\hline No. & G & $\chi^{2}(0,05: 1)$ \\
\hline 1. & 23,881 & 3,841 \\
\hline
\end{tabular}




\section{$A I \overline{I E B} \quad$ Annual International Conference \\ on Islamic Economics and Business, 2021}

The results of the statistical analysis of the test using the Log Likelihood (G) value can be explained that by referring to the $\mathrm{G}$ value which is greater than the value of 3.841 , the model is significant. It can be concluded that the model is formed with predictor variables that have fulfilled the assumption that it has a significant multivariate effect. In other words, the best model is formed by all significant predictor variables

\subsection{Parameter Coefficient Significance Test Model}

The next step of analysis is to test the significance of the model parameter coefficients. This test is used to determine whether there is an effect of each predictor variable that has a significant effect on the response variable. The results of the analysis of the parameter coefficients of the multivariate binary logistic regression model are shown in Table 2

Table 2. Coefficient Significance Test.

\begin{tabular}{|c|c|c|c|c|l|}
\hline Variable & $\mathrm{B}$ & $\mathrm{S} . \mathrm{E}$ & Wald & p-value & Decision \\
\hline $\mathrm{X}_{1}$ & 4,254 & 1,984 & 4,597 & 0,032 & Reject $\mathrm{H}_{0}$ \\
\hline $\mathrm{X}_{2}$ & 7,592 & 2,550 & 8,868 & 0,003 & Reject $\mathrm{H}_{0}$ \\
\hline $\mathrm{X}_{3}$ & 6,525 & 2,039 & 10,240 & 0,001 & Reject $\mathrm{H}_{0}$ \\
\hline $\mathrm{X}_{4}$ & 5,666 & 1,616 & 12,291 & 0,000 & Reject $\mathrm{H}_{0}$ \\
\hline $\mathrm{X}_{5}$ & 5,077 & 1,778 & 8,155 & 0,004 & Reject $\mathrm{H}_{0}$ \\
\hline Constant & $-15,184$ & 4,786 & 10,065 & 0,002 & Reject $\mathrm{H}_{0}$ \\
\hline
\end{tabular}

Table 2 shows the test results of the parameter coefficients of the binary logistic regression model. The decision to reject $\mathrm{H}_{0}$ or accept $\mathrm{H}_{0}$ can be seen from the $\mathrm{p}$-value, if the p-value is less than the value of the $5 \%$ significance level $(\alpha)$ then the decision is to reject $\mathrm{H}_{0}$ , and vice versa. So the table above informs that the decision obtained for all predictor variables is to reject $\mathrm{H}_{0}$ because the p-value is less than $5 \%$ or 0.05 , which means that all of these variables have a significant effect on the response variable. As for the form of the multivariate binary logistic regression model produced, the logit transformation equation is obtained as follows.Data Sources, Variables, and Measurement Scales

The independent variables in this study include convenience (X1), benefits (X2), security (X3), convenience (X4) and knowledge (X5), and the dependent variable in the study includes student interest in using e-banking (Y). The measurement scale used in this study is a nominal scale.

$$
g(x)=-15,184+4,254 X_{1}+7,592 X_{2}+6,525 X_{3}+5,666 X_{4}+5,077 X_{5}
$$

The resulting probability function is as follows:

$$
\pi(X)=\frac{\exp \left(-15,184+4,254 X_{1}+7,592 X_{2}+6,525 X_{3}+5,666 X_{4}+5,077 X_{5}\right)}{1+\exp \left(-15,184+4,254 X_{1}+7,592 X_{2}+6,525 X_{3}+5,666 X_{4}+5,077 X_{5}\right)}
$$

Based on these equations, it can be calculated that the probability of respondents being interested in the statement "yes" to the ease, convenience, security, convenience and knowledge of the interest in using e-banking is 0.998 . The probability that the respondent is not interested in the "no" statement on all these variables is 0.002 . Based on the results of the analysis, it is also shown that all variables have a significant positive effect on the interest in using e-banking 


\section{$\mathrm{AIC} \overline{I E B}$

\subsection{Model Fit Test}

Binary logistic regression is a method of regression analysis that describes the relationship between the response variable (dependent) and one or more predictor variables (independent). In binary logistic regression, the given model with p predictor variables is as follows. An important test in binary logistic regression analysis is the suitability test of the model formed. This test is used to see if there is a difference between the observed results and the possible predictions of the model. The following are the results of the conformity test of the formed model which are shown in Table 3.

Table 3. Model Fit Test

\begin{tabular}{|c|c|c|c|c|}
\hline$\chi^{2}$ hiutng & df & $\chi^{2}(0,05: 3)$ & p-value & Decision \\
\hline 0,052 & 3 & 7,814 & 0,997 & Accept $\mathrm{H}_{0}$ \\
\hline
\end{tabular}

Table 3 Based on the results obtained value of the test statistic $\chi 2$ hiutng at 0,052 . This value is less than the table value $\chi^{2}(0,05: 3)$ is 7,814 . Another value, namely the $p$-value, shows a fairly large value of 0.997 which exceeds $5 \%$. So the conclusion drawn is accept H0 . The conclusion shows that the multivariate binary logistic regression model for the attributes of questions related to convenience, benefit, security, convenience, and knowledge is appropriate in measuring the determinants of interest in using e-banking. In other words, the model is suitable, which means that there is no difference between the observed results and the possible predictions of the model .

\subsection{Model Interpretation}

The interpretation stage of the logistic regression model is using the odds ratio value, which is useful for explaining the functional relationship between the response variable and the predictor variable. On the other hand, the odds ratio value is also used to determine the effect of a variable on the decision to use e-banking.

Table 4. Odds Ratio

\begin{tabular}{|c|c|}
\hline Variable & Odds Ratio \\
\hline $\mathrm{X} 1$ & 70,352 \\
\hline $\mathrm{X} 2$ & 1982,811 \\
\hline $\mathrm{X} 3$ & 681,713 \\
\hline $\mathrm{X} 4$ & 288,811 \\
\hline $\mathrm{X} 5$ & 160,265 \\
\hline
\end{tabular}

Based on Table 4, it can be interpreted that respondents who consider ease of use tend to be more interested in using e-banking by 70.352 times greater than respondents who do not consider ease of use. The conclusion is that respondents who choose the answer option "yes" in determining ease of use tend to decide to be interested in using e-banking. Meanwhile, when measured from the benefit variable, respondents who consider the benefits of using ebanking tend to be more interested in using e-banking, which is 1982,811 times greater than respondents who do not consider the benefits of using it. The conclusion is that respondents who choose the answer option "yes" in determining the benefits of use tend to decide to be interested in using e-banking . 


\section{$A \mathrm{ICB} \quad$ Annual International Conference \\ on Islamic Economics and Business, 2021}

Respondents who consider the use of security variables tend to be more interested in using e-banking by 681.713 times greater than respondents who do not consider the security of use. The conclusion is that respondents who choose the answer option "yes" in determining the security of use tend to decide to be interested in using e-banking . Meanwhile, when measured from the convenience variable, respondents who consider the convenience of use tend to be more interested in using e-banking by 288.811 times greater than respondents who do not consider the convenience of use. The conclusion is that respondents who choose the answer option "yes" in determining the convenience of use tend to decide to be interested in using ebanking .

If it is measured from the knowledge variable, respondents who consider having a lot of knowledge about e-banking tend to be more interested in using e-banking by 160.265 times greater than respondents who do not consider e-banking knowledge. The conclusion is that respondents who choose the answer option "yes" in determining having knowledge tend to decide to be interested in using e-banking. Based on the results of research and discussion, some conclusions can be drawn as follows that the variables of convenience, benefit, security, comfort and knowledge simultaneously have a positive and significant influence on the interest of students of the Islamic Banking Department in using e-banking. All of predictor variables have a positive and significant impact on the interest of Islamic Banking Department students in using e-banking.

\section{Conclusion}

Based on the results of research and discussion, some conclusions can be drawn as follows that the variables of convenience, benefit, security, comfort and knowledge simultaneously have a positive and significant influence on the interest of students of the Islamic Banking Department in using e-banking. All of predictor variables have a positive and significant impact on the interest of Islamic Banking Department students in using e-banking.

\section{References}

Adi Pratama dkk. 2019. Faktor-Faktor Yang Mempengaruhi Niat Dalam Menggunakan Mobile Banking (Studi Empiris Pada Nasabah Perbankan Konvensional Di Kota Palu). Jurnal Akun Nabelo, Vol. 2, No. 1.

Almatius Setya Marsudi, Yunus Widjaja. 2019. Industri 4.0 Dan Dampaknya Terhadap Financial Technology Serta Kesiapan Tenaga Kerja Di Indonesia. Jurnal Ikraith ekonomika, Vol. 2, No. 2.

Ani Luluk Mauludiyah, Nur Diana. 2018 Pengaruh Kepercayaan, Keamanan, Persepsi Risiko, Serta Kesadaran Nasabah Terhadap Adopsi E-Banking Di Bank Bri Kantor Kas Universitas Islam Malang. Jurnal Akuntansi, Vol. 07, No. 07.

Assauri Sofjan. 2018. Manajemen Pemasaran. Jakarta : PT Raja Grafindo.

Budi Raharjo. 2005. Keamanan Sistem Informasi Berbasis Internet. Bandung: PT Insan Infonesia.

Chitra Laksmi Rithmaya. 2016. Pengaruh Kemudahan Penggunaan, Kemanfaatan, Sikap, Risiko dan Fitur Layanan Terhadap Minat Ulang Nasabah Bank BCA dalam Mengggunakan Mobile Banking. Jurnal Riset Ekonomi Dan Manajemen, Vol. 16, No.1.

Djali. 2008. Psikologi Pendidikan. Jakarta: Bumi Aksara.

Fahrul Rozi, Muhammad Ziyad. 2019. Pengaruh Kepercayaan, Persepsi Kegunaan, Persepsi Kemudahan Dan Persepsi Kenyamanan Terhadap Minat Menggunakan 


\section{$A \mathrm{ICB}$ Annual International Conference \\ on Islamic Economics and Business, 2021}

Layanan Mobile Banking Bank BTN. Jurnal Sains Manajemen dan Kewirausahaan, Vol. 3, No. 2.

Fauziati, Popi. 2010. Analisis Faktor-Faktor Yang Mempengaruhi Penerimaan Nasabah Terhadap Layanan Internet Banking Dengan Menggunakan Pendekatan Technology Acceptance Model (TAM). Jurnal Kajian Akuntansi dan Auditing, Vol. 7, No. 2.

Giga Bawa Laksana, Endang Siti Astuti dan Rizki Yudhi Dewantara. 2015. Pengaruh Persepsi Kemanfaatan, Persepsi Kemudahan Penggunaan, Persepsi Resiko Dan Persepsi Kesesuaian Terhadap Minat Menggunakan Mobile Banking (Nasabah Bank Rakyat Indonesia (BRI) Kantor Cabang Rembang, Jawa Tengah). Jurnal Administrasi Bisnis, Vol. 26, No.2.

Haris Faulidi Asnawi dan M. Lukman. 2004. Transaksi Bisnis E-Commerce Perspektif Islam. Yogyakarta: Magistra Insania Press.

I. Adamson and J. Shine. 2003. Extending The New Technology Acceptance Model To Measure The User Information System Satisfaction In A Mandatory Environtment: A Bank's Treasury. Technology Analysis \& Strategic Management, Vol. 15, No.4.

Imam Yahya, Retnandi Meita Putri. 2016. Pengaruh Perubahan Biaya Transaksi Kartu ATM (Anjungan Tunai Mandiri) Pada Tabungan Faedah Terhadap Minat Bertransaksi Nasabah Di BRI Syariah KC Semarang. Jurnal Economica, Volume VII, Edisi 1.

J.P Chaplin. 2008. Kamus Psikologi, Lengkap. Jakarta: Raja Grafindo.

Jogiyanto. 2007. Sistem Informasi Keperilakuan Edisi Revisi. Yogyakarta: Andi Offset. Jogiyanto. 2008. Sistem Teknologi Informasi Edisi III. Yogyakarta: ANDI.

John C. Mowen dan Michael Minor. 2002. Perilaku Konsumen Jilid I. Jakarta: Erlangga.

Lovelock \& Gummesson E. 2004. Whither services marketing? In search of a new paradigm and fresh perspectives. Journal of service research, Vol.7, No.1.

M. Yusnita. 2010. Pola Perilaku Konsumen dan Produsen. Semarang : Penerbit Alprin.

Maria Loki Kristianti dan Rilo Pambudi. 2018. Analisis Pengaruh Persepsi Kemudahan, Persepsi Kemanfaatan, Persepsi Tingkat Keamanan, Dan Fitur Layanan Terhadap Penggunaan Mobile Banking Pada Mahasiswa Di DKI Jakarta. Jurnal Akuntansi, Vol. 11, No. 1.

Mario Ledesman. 2018. Pengaruh Manfaat, Kepercayaan,dan Kemudahan Penggunaan Terhadap Minat Nasabah Menggunakan Layanan Mobile Banking". Skripsi, Universitas Islam Negeri Raden Intan: Lampung.

Maryanto Supriyanto. 2011. Buku Pintar Perbankan. Yogyakarta: ANDI.

Misna dkk. 2018. Analisis Regresi Logistik Biner Untuk Mengklasifikasi Penderita Hipertensi Berdasarkan Kebiasaan Merokok Di RSU Mokopido Toli-Toli. Journal of Science and Technology, Vol. 7, No. 3.

Muhammad Fadhli, Rudy Fachruddin. 2016. Pengaruh Persepsi Nasabah atas Risiko, Kepercayaan, Manfaat, dan Kemudahan Penggunaan terhadap Penggunaan Internet Banking. Jurnal Ekonomi Akuntansi, Vol. 1, No.2.

Muinah Kusnul Kotimah dan Sri Pingit Wulandari. 2014. Model Regresi Logistik Biner Stratifikasi Pada Partisipasi Ekonomi Perempuan Di Provinsi Jawa Timur. Jurnal Sains dan Seni Pomits, Vol. 3, No.1.

Nauman Zahid, Asif Mujtaba dan Adnan Riaz. 2010. Consumer Acceptance Of Online Banking, European. Journal Of Economic Finance and Administrative Sciences, Vol. 27, No. 1.

Nelson Tampu Bolon. 2015. Bijak Ber-eBanking. Jakarta: OJK.

Nina Rizky dkk. 2018. Pengaruh Persepsi Kemudahan Penggunaan, Kepercayaan, Dan Pengetahuan Terhadap Minat Menggunakan E-Banking dalam Bertransaksi pada Umkm di Kecamatan Buleleng. Jurnal Ilmiah Mahasiswa Akuntansi, Vol. 9, No.3. 


\section{$A I C \bar{C} \quad$ Annual International Conference \\ on Islamic Economics and Business, 2021}

Nugroho Setiadi. 2015. Perilaku Konsumen: Konsep Dan Implikasi Untuk Strategi dan Penelitian Pemasaran. Bogor: Kencana.

Panggih Rizky Dwi Istiarni. 2014. Analisis pengaruh persepsi manfaat, kemudahan penggunaan dan kredibilitas terhadap minat penggunaan berulang internet banking dengan sikap penggunaan sebagai variabel intervening. Semarang: Skripsi tidak diterbitkan.

Philip Kotler. 2001. Manajemen Pemasaran Indonesia. Jakarta: Salemba Empat.

Pupu Saeful Rahmat. 2018. Psikologi Pendidikan. Jakarta: PT Bumi Aksara.

Rini Widianingsih. 2017. Implementasi Brinets Terhadap Kinerja Pegawai dengan Perceived Enjoyment dan computer Plyafulness sebagai Variabel Moderating. Jurnal Analisis Bisnis Ekonomi, No. 1, Vol. 15.

Samsul Hadi dan Novi. 2017. Faktor-Faktor Yang Mempengaruhi Penggunaan Layanan Mobile Banking. Jurnal Ekonomi Bisnis dan Akuntansi, Vol. 4, No. 1.

Sartika Sari Ayu Tjini dan Zaki Baridwan. 2013. Pengaruh Kepercayaan, Persepsi Kegunaan, Persepsi Kemudahan, dan Persepsi Kenyamanan Terhadap Minat Penggunaan Sistem Internet Banking. Jurnal Mahasiswa FEB, Vol.1 No.2.

Shaleh Abdul Rahman dan Muhib Abdul Wahab. 2004. Psikologi Suatu Pengantar Dalam Perspektif Islam. Jakarta: Kencana.

Sherly Rakhmawati, Isharijadi. 2013. Pengaruh Kepercayaan, Peesepsi Kegunaan, Persepsi Kemudahan, Dan Persepsi Kenyamanan Terhadap Minat Penggunaan Sistem Internet Banking Pada Nasabah Bank Muamalat Cabang Pembantu Madiun. Jurnal Akuntansi dan Pendidikan, Vol.2, No.2.

Siregar Sofyan. 2012. Statistik Parametrik untuk Penelitian Kuantitatif. Yogyakarta: Bumi Aksara.

Slamet. 2010. Belajar dan Faktor-Faktor yang Mempengaruhinya. Jakarta: PT. Rineka Cipta.

Sri Bulkia dkk. 2019. Pengaruh Pengetahuan Nasabah dan Kualitas Layanan terhadap Minat Individu Pengguna Internet Banking Banjarmasin. Jurnal Ilmiah Manajemen, Vol. 3, No.2.

Sri Yuniarti Vinna. 2015. Perilaku Konsumen Teori dan Praktik. Bandung: Pustaka Setia.

Steven Taylor A And Baker. 1994. An Assessment Of The Relationship Between Service Quality And Customer Satisfaction In The Information Of Customer Purchase Intentions. Journal Of Retailing Vo.70 No.2.

Sugiyono. 2016. Metode Penelitian Kuantitatif, Kualitatif dan $R \& D$. Bandung: Alfabeta.

Sugiyono. 2018. Metode Penelitian Kuantitatif. Bandung:Alfabeta.

Suryani Tatik. 2013. Perilaku Konsumen di Era Internet. Yogyakarta: Graha Ilmu.

Swastha Basu, Irawan. 2000. Manajemen Pemasaran Modern Ed. 2. Yogyakarta: Liberty.

Tjiptono Fandy. 2004. Manjemen Jasa. Yogyakarta: Andi.

Ujang Sumarwan. 2003. Pengetahuan Konsumen Teori dan Penerapannya Dalam Pemasaran. Jakarta: Ghalia Indonesia.

Ujang Sumarwan. 2003. Perilaku Konsumen. Jakarta: Ghalia Indonesia.

Venkatesh dan Davis F. D. 2000. A Theoretical Extension of the Technology Acceptance Model: Four Longitudinal Field Studies. Management Science, Vol. 46 No. 2.

Widia Permana dkk. 2012. Perpustakaan Nasional: Katalog dalam Terbitan (KDT) Layanan Perpustakaan via Mobile Data Cetakan Pertama. Malang: UB Press.

YantiAngraeni dkk, 2015. Permodelan Regresi Logistik Biner terhadap peminat ITS di Seleksi Bersama Masuk PTN 2014. Jurnal Sains dan Seni ITS, Vol 4, No.1. 